\title{
Permanence of amnesia after single posttrial treatments of Metrazol or electroconvulsive shock '
}

\author{
J. PETER KINCAID 2 \\ ROOSEVELT UNIVERSITY
}

Interference with retention induced by a single administration of electroconvulsive shock or Metrazol after one-trial training was demonstrated to be relatively permanent. Electroconvulsive shock administered approximately $75 \mathrm{sec}$ after training and Metrazol administered 5 min after training resulted in retrograde amnesia which persisted undiminished in strength for 21 days.

It has been demonstrated that a single treatment of either electroconvulsive shock (ECS) or the convulsant drug, penthylenetetrazol (Metrazol), results in subsequent interference with retention of a response learned in one trial (Kincaid, 1967; Chorover \& Schiller, 1965; Quartermain, Paolino, \& Miller, 1965; Pearlman, Sharpless, \& Jarvik, 1961). An assumption implicit in these studies is that this interference with retention is permanent. The test for retention has characteristically been given within $24 \mathrm{~h}$ after training. However, Chevalier (1965), using a conditioned emotional response technique, produced retrograde amnesia in mice with ECS which did not significantly diminish in strength over a perlod of 30 days following training.

The present experiment evaluates the permanence of amnesia induced by ECS, using a different species and a different training procedure than Chevalier (1965). It also evaluates the permanence of amnesia induced by Metrazol.

According to the consolidation hypothesis, retrograde amnesia induced by posttrial administration of various agents should be permanent. The criterion of permanence used in the present experiment was that the induced retrograde amnesia should persist over a period of 21 days.

Subjects

Eighty-two Sprague-Dawley rats of both sexes were 60-80 days old and experimentally naive at the time of training. Of these $82 \mathrm{Ss}, 25$ were eliminated during the course of the experiment for reasons described below.

Apparatus

The apparatus, identical to that described by Kincaid (1967), was a step down device consisting of a $5 \times 5 \times$ 7 in. startbox separated from a $16 \times 16 \times 10$ in. Masonite and Plexiglas compartment by a sliding Plexiglas door. The startbox was raised manually and lowered to the grid floor of the large compartment by means of a small motor. A 60 cycle, ac grid shock of approximately $0.5 \mathrm{~mA}$ could be dellvered for a timer-controlled
(Hunter Model 115) period of $2.0 \mathrm{sec}$. The ECS consisted of an automatically timed $0.3 \mathrm{sec}, 540 \mathrm{~V}, 60$ cycle sine wave stimulus delivered to the ears through moist padded alligator clips.

\section{Procedure}

During the training session, the Ss were given a $1 \mathrm{~min}$ adaptation period, after which the startbox was lowered to the level of the large compartment. When a $\mathrm{S}$ in a grid shock group had placed all four feet on the grid floor, the sliding door was closed and grid shock was delivered for $2.0 \mathrm{sec}$. Ss in the control groups receiving no grid shock were required to step onto the grid floor and the sliding door was closed. Eleven out of the original $82 \mathrm{Ss}$ falled to step out of the starting compartment within $30 \mathrm{sec}$ and were eliminated from the study. This insured that Ss had no initial reluctance to respond. Acceptable Ss were removed to a holding cage immediately after the training trial. ECS Ss receiving grid shock were administered the convulsive treatment approximately 75 sec after stepping out of the starting compartment. The treatment was given on a table adjacent to the training apparatus under the conditions described. All ECS Ss had full tonic extensor seizures. Metrazol Ss received $65 \mathrm{mg} / \mathrm{kg}$ of the drug through an IP route. This dose was selected to produce a high incidence of clonic seizures; tonic seizures were fatal too frequently to be studied. Onset of Metrazol convulsions occurred on the average of $75 \mathrm{sec}$ after injection, and typically lasted $10 \mathrm{sec}$. Metrazol Ss were then observed in a transparent holding cage for $5 \mathrm{~min}$. Eight out of the surviving 28. Metrazol Ss did not manifest either multiple clonic jerks or a clonic seizure during the $5 \mathrm{~min}$ observation period following injection and were eliminated from the sample. "Multiple jerks" consisted of rapid spasmodic movements of the head and neck. Twelve out of the original 82 Ss died. All ECS and Metrazol Ss were kept in a holding cage for about $30 \mathrm{~min}$ after treatment to permit recovery, before being returned to the home cage. The Ss were tested in the same apparatus $24 \mathrm{~h}$ after training. Failure to leave the starting compartment within $3 \mathrm{~min}$ was taken as evidence that the passive avoldance response had been learned and retained. Ss in the groups receiving grid shock and either Metrazol or ECS were retested 21 days after testing.

Results

Table 1 contains a summary of the results. Eight out of 10 of the $\mathrm{Ss}$ receiving a Metrazol injection $5 \mathrm{~min}$ 
Table 1

Proportion of Ss responding (stepping down) on test and retest trials (Retest given 21 days after test)

\begin{tabular}{|c|c|c|c|}
\hline & \multicolumn{2}{|c|}{ Test } & Retest \\
\hline \multirow{3}{*}{$\begin{array}{l}\text { Convulsive } \\
\text { Treatment }\end{array}$} & \multirow{2}{*}{\multicolumn{2}{|c|}{$\begin{array}{c}\text { Grid } \\
\text { Shock }\end{array}$}} & Grid \\
\hline & & & Shock \\
\hline & No & Yes & Yes \\
\hline None & $10 / 10$ & $1 / 10$ & \\
\hline Metrazol & $9 / 10$ & $8 / 10$ & $7 / 8$ \\
\hline ECS & $8 / 10$ & $7 / 10$ & $4 / 9$ \\
\hline
\end{tabular}

after receiving grid shock stepped down from the starting compartment during the test trial; the other two Ss were considered to have retained the learned response. Only one of the $10 \mathrm{Ss}$ receiving grid shock, but no convulsive treatment, stepped down during the test trial. The two classification variables (presence or absence of stepping down and presence or absence of Metrazol treatment) exhibited a significant lack of independence when evaluated using Fisher's exact probability test. The probability of obtaining a discrepancy this large or larger was $\mathbf{0 0 7}$. This distribution of frequencies suggests that Metrazol caused retrograde amnesia. The group receiving grid shock followed approximately 75 sec later by ECS also demonstrated retrograde amnesia as seven out of 10 Ss stepped down on the test trial; again, the variables used in a comparison of this group and those of the group that received grid shock but no convulsive treatment were not independent $(p=.05)$. The control groups (the three groups not recelving grid shock) did not differ significantly from one another. In these groups, $8 / 10,9 / 10$, and $10 / 10$ stepped down during the test trial, indicating that the ECS and Metrazol treatments, by themselves, had no aversive effects.

During the retest trial, given 21 days after the test trial, 4 out of 9 of the group that received grid shock and Metrazol stepped down; 8 out of 10 of this group stepped down on the test trial. The probability of obtaining a discrepancy this large or larger is .58, indicating that the retrograde amnesia was retained.
Retrograde amnesia induced by ECS was also retained over the 21 day period as 7 out of 10 Ss stepped down on the test trial and 4 out of $9 \mathrm{Ss}$ stepped down on the retest trial $(p=.17)$. Two $S s$ died in the grid shockMetrazol group, and one died in the grid shock-ECS group between the test and retest.

\section{Discussion}

The present experiment confirmed for the rat a finding obtained previously in mice, namely, that a single posttrial treatment of ECSproduces permanent interference with retention. In addition, it extends this finding to include the action of Metrazol. These findings support the consolidation hypothesis to the extent that it is implicit in the hypothesis that retrograde amnesia induced by various agents is permanent. In addition it extends the generality of the finding by Chevalier (1965).

However, the question remains: Why should ECS and Metrazol act differentially in producing retrograde amnesia (Kincaid, 1967), and yet be similar in that the interference with retention produced by both agents is permanent? An answer to this question will serve to throw light on the consolidation hypothesis.

\section{References}

CHEVALIER, J. A. Permanence of amnesia after a single posttrial electroconvulsive seizure. J. comp. physiol Psychol, 1965, 59, 125-127.

CHOROVER, S. L., \& SCHILLER, P. H. Short-term retrograde amnesia in rats. J. comp. physiol. Psychol, 1965, 59, 73-78.

HAYS, W. L. Statistics for psychologists. New York: Holt, Rinehart and Winston, 1963.

KINCAID, J. P. A comparison of the retrograde amnesic effects of Metrazol and electroconvulsive shock. Psychon. Sci, in press.

PEARLMAN, C. A., SHARPLESS, S. K., \& JARVIK, M. E. Retrograde amnesia produced by anesthetic and convulsant agents. $J$. comp. physiol. Psychol., 1961, 54, 109-112.

QUARTERMAIN, D, PAOLINO, R. M., \& MILLER, N. E. A brief temporal gradient of retrograde amnesia independent of situation change. Science, $1965,149,1116-1118$.

Notes

1. This research is based upon a thesis submitted by the author in partial fulfillment of the requirements for the M.A. degree in psychology at Roosevelt University.

2. Now with the Personnel Subsystems Branch (SEG/SEMCP), WrightPatterson Air Force Base, Ohio 45433. 